\title{
Review Article \\ Greenhouse Gases Emissions from Wastewater Treatment Plants: Minimization, Treatment, and Prevention
}

\author{
J. L. Campos, ${ }^{1}$ D. Valenzuela-Heredia, ${ }^{1}$ A. Pedrouso, ${ }^{2}$ A. Val del Río, ${ }^{2}$ \\ M. Belmonte, ${ }^{3,4}$ and A. Mosquera-Corral ${ }^{2}$ \\ ${ }^{1}$ Facultad de Ingeniería y Ciencias, Universidad Adolfo Ibáñez, Avenida Padre Hurtado 750, 2520000 Viña del Mar, Chile \\ ${ }^{2}$ Department of Chemical Engineering, School of Engineering, University of Santiago de Compostela, Rua Lope Gómez de Marzoa s/n, \\ 15782 Santiago de Compostela, Spain \\ ${ }^{3}$ Department of Environment, Faculty of Engineering, University of Playa Ancha, Avenida Leopoldo Carvallo 270, \\ 2340000 Valparaíso, Chile \\ ${ }^{4}$ School of Biochemical Engineering, Pontifical Catholic University of Valparaíso, Avenida Brasil 2085, 2340000 Valparaíso, Chile
}

Correspondence should be addressed to J. L.Campos; jluis.campos@uai.cl

Received 28 December 2015; Revised 29 March 2016; Accepted 5 April 2016

Academic Editor: Claudio Di Iaconi

Copyright (C) 2016 J. L. Campos et al. This is an open access article distributed under the Creative Commons Attribution License, which permits unrestricted use, distribution, and reproduction in any medium, provided the original work is properly cited.

\begin{abstract}
The operation of wastewater treatment plants results in direct emissions, from the biological processes, of greenhouse gases (GHG) such as carbon dioxide $\left(\mathrm{CO}_{2}\right)$, methane $\left(\mathrm{CH}_{4}\right)$, and nitrous oxide $\left(\mathrm{N}_{2} \mathrm{O}\right)$, as well as indirect emissions resulting from energy generation. In this study, three possible ways to reduce these emissions are discussed and analyzed: (1) minimization through the change of operational conditions, (2) treatment of the gaseous streams, and (3) prevention by applying new configurations and processes to remove both organic matter and pollutants. In current WWTPs, to modify the operational conditions of existing units reveals itself as possibly the most economical way to decrease $\mathrm{N}_{2} \mathrm{O}$ and $\mathrm{CO}_{2}$ emissions without deterioration of effluent quality. Nowadays the treatment of the gaseous streams containing the GHG seems to be a not suitable option due to the high capital costs of systems involved to capture and clean them. The change of WWTP configuration by using microalgae or partial nitritationAnammox processes to remove ammonia from wastewater, instead of conventional nitrification-denitrification processes, can significantly reduce the GHG emissions and the energy consumed. However, the area required in the case of microalgae systems and the current lack of information about stability of partial nitritation-Anammox processes operating in the main stream of the WWTP are factors to be considered.
\end{abstract}

\section{Introduction}

In the past years most efforts to improve wastewater treatment plants (WWTPs) performance have been focused on obtaining a good effluent quality [1-5]. However nowadays, new challenges are under consideration, oriented to ensure the sustainability of WWTPs in terms of their economic feasibility and environmental impact. Energy consumption and greenhouse gases (GHG) emissions are among the aspects that have become key-factors concerning the overall performance of the WWTPs [6,7]. Recent studies have identified the WWTPs as potential sources of anthropogenic GHG emissions, contributing to climate change and air pollution [8-10]. WWTPs produce carbon dioxide $\left(\mathrm{CO}_{2}\right)$, methane $\left(\mathrm{CH}_{4}\right)$, and nitrous oxide $\left(\mathrm{N}_{2} \mathrm{O}\right)$ during the biological wastewater treatment processes and $\mathrm{CO}_{2}$ is also emitted during the production of the energy required for the plant operation. The $\mathrm{CO}_{2}$ released due to the energy demand can be directly reduced by enhancing the energy efficiency of the WWTPs. In this way both the reduction of environmental impacts and the decrease of treatment costs by enhancing the energy savings can be accomplished simultaneously.

With regard to each GHG source the $\mathrm{N}_{2} \mathrm{O}$ emitted is generated by nitrification and denitrification processes used to remove nitrogenous compounds from wastewater. Its production occurs mainly in the activated sludge units (90\%) while the remaining $10 \%$ comes from the grit and sludge storage tanks [11]. $\mathrm{N}_{2} \mathrm{O}$ gas is an intermediate of biological 


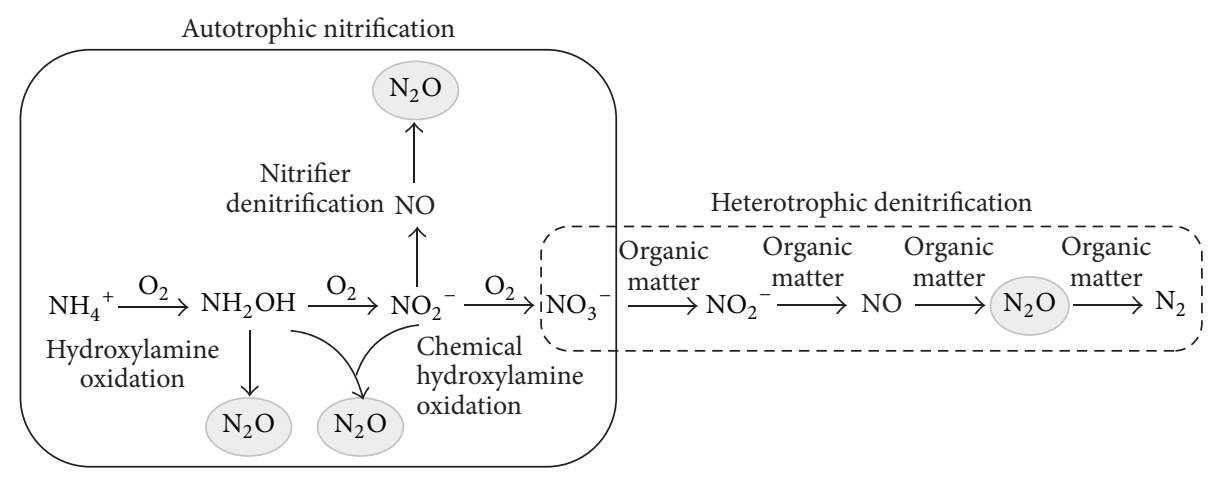

FIGURE 1: Biological and chemical pathways of $\mathrm{N}_{2} \mathrm{O}$ production in the nitrification and denitrification processes.

processes such as heterotrophic denitrification and nitrification (Figure 1). It is formed during denitrification operated at low $\mathrm{pH}$ values and toxic compounds or low dissolved oxygen (DO) concentrations are present in the media [12-14]. Nitrifying bacteria are able to produce $\mathrm{N}_{2} \mathrm{O}$ under aerobic or anoxic [15] conditions. In anoxic conditions, both ammoniaand nitrite-oxidizing bacteria are able to produce it, while only ammonia-oxidizing bacteria do it in aerobic conditions. In the latter case, the production is stimulated by the presence of low DO concentrations and presence of nitrite $\left(\mathrm{NO}_{2}{ }^{-}\right)$or organic matter in the liquid media $[12,13]$. Nitrous oxide can be produced also from chemical reactions taking place in the presence of hydroxylamine and nitrite [16].

In practice nitrous oxide is emitted in the WWTP predominantly in the aerobic tank [17]. However, the contribution of the anoxic and aerobic reactors to this production remains still unclear since it can be produced in the anoxic stage and be subsequently stripped to the gas phase in the aerated compartment [18]. Ammonia-oxidizing bacteria have been identified as the main $\mathrm{N}_{2} \mathrm{O}$ producers while heterotrophic denitrifying bacteria contribution is only relevant when nitrite and/or oxygen are present in the anoxic stage [19]. According to Tallec et al. [20], under common operational conditions, the $\mathrm{N}_{2} \mathrm{O}$ production occurs mainly via denitrification by nitrifying bacteria. However hydroxylamine oxidation pathway can be the main process responsible for the production of $\mathrm{N}_{2} \mathrm{O}$ emissions at high ammonia $\left(\mathrm{NH}_{4}{ }^{+}\right)$and low nitrite concentrations, when a high metabolic activity of ammonia-oxidizing bacteria is present (at 2 to $3 \mathrm{mg} \mathrm{O}_{2} / \mathrm{L}$ ) [19].

With regard to $\mathrm{CH}_{4}$ emissions, Daelman et al. [21] found out that about $1 \%$ of the incoming chemical oxygen demand (COD) to the WWTPs was emitted as methane. This amount exceeds the amount of carbon dioxide emission that was avoided by utilizing the produced biogas in anaerobic digestion. The main sources of methane detected by these authors were related to the sludge line units where anaerobic digestion is carried out: the primary sludge thickener, the centrifuge, the exhaust gas of the cogeneration plant, the buffer tank for the digested sludge, and the storage tank for the dewatered sludge. These units contribute to around $72 \%$ of methane emissions of the WWTPs while the remaining emissions come from the biological reactors and can be mainly attributed to the $\mathrm{CH}_{4}$ dissolved in the wastewater which is not totally removed by the biological system. Research works of Yver Kwok et al. [22] and Oshita et al. [23] also showed that most of the methane emissions from WWTPs are closely related to processes involved in the sludge line.

With respect to $\mathrm{CO}_{2}$ its production is attributed to two main factors: biological treatment process and electricity consumption. In the main stream of the WWTP the organic carbon of wastewater is either incorporated into biomass or oxidized to $\mathrm{CO}_{2}$. In the sludge line, it is converted mainly to $\mathrm{CO}_{2}$ and $\mathrm{CH}_{4}$ during anaerobic digestion and, finally, methane is oxidized to $\mathrm{CO}_{2}$ during biogas combustion.

In recent literature the emissions of GHG from the conventional configurations of WWTPs were determined but the analysis of the possible alternatives to minimize these emissions is generally not done [24-28]. On the other hand, most of the papers studying the application of new processes to remove pollutants from wastewaters are mainly focused on the energy savings [29-32] and only few of them also give an environmental evaluation [33-36]. Therefore, the main objective of this work is to provide an overview of all possible ways to reduce GHG emissions from WWTPs. For that, two possible scenarios are discussed and analyzed: (1) to maintain the present scheme of operation of the WWTP and to modify the operational conditions (minimization) or to implement capture and treatment units for the gaseous streams (treatment) and (2) to change the scheme of operation and to implement new processes which produce lower GHG emissions than the existing ones (prevention).

\section{Minimization of GHG Emissions}

Perhaps, the most efficient way, in terms of costs, to reduce GHG emissions is to modify the operational conditions of WWTPs units but this is not always possible due to the operational limitations of the installed units. In the following sections, some recommendations about the possible actions to put in practice to operate WWPTs in order to reduce GHG emissions are provided.

2.1. $\mathrm{N}_{2} \mathrm{O}$ Production. Data obtained from the operation of full-scale WWTPs show a wide range of values for the 
fraction of nitrogen that is emitted as $\mathrm{N}_{2} \mathrm{O}(0-14.6 \%$ of the nitrogen load) [12]. Such large variation can be related to the different operational conditions imposed in the studied WWTPs. Having this in mind decreasing the amounts of $\mathrm{N}_{2} \mathrm{O}$ emitted from activated sludge processes presents a great potential for improvement, by avoiding those operational conditions identified as responsible for its production. Some identified conditions are (i) low dissolved oxygen concentration in the nitrification and the presence of oxygen in denitrification stages, (ii) high nitrite concentrations in both nitrification and denitrification stages, (iii) low $\mathrm{COD} / \mathrm{N}$ ratio in the denitrification stage, (iv) sudden shifts of $\mathrm{pH}$ and dissolved oxygen and ammonia and nitrite concentrations, and (v) transient anoxic and aerobic conditions [12, 13].

Therefore, to minimize $\mathrm{N}_{2} \mathrm{O}$ emissions, biological wastewater treatment plants should be operated at high solid retention times (SRT) to maintain low ammonia and nitrite concentrations in the media. Furthermore large bioreactor volumes are recommended to dispose of systems able to buffer loadings and reduce the risk of transient oxygen depletion. $\mathrm{N}_{2} \mathrm{O}$ emissions can be also reduced if nitrous oxide stripping by aeration is limited since microorganisms would have more time to consume it [37].

2.2. $\mathrm{CH}_{4}$ Production. $\mathrm{CH}_{4}$ emissions can be minimized if thickening sludge tanks and sludge disposal tanks are covered to avoid gas leakages and their emissions are captured by hoods which could be burnt with excess biogas in a torch [21]. Besides the methane produced in the plant itself, methane also enters the plant from outside via the influent since it contains $\mathrm{CH}_{4}$ that has been formed in the sewer. The methane load was estimated as $1 \%$ of the influent COD load and is mainly oxidized in the activated sludge tanks $(80 \%)$, which could be exploited as a means to further decrease methane emissions from wastewater treatment [21].

2.3. $\mathrm{CO}_{2}$ Production. Organic matter oxidation in the biological reactors and combustion of $\mathrm{CH}_{4}$ are responsible for the direct $\mathrm{CO}_{2}$ emissions while indirect emissions are attributed to the energy consumption of the WWTP [26]. The SRT applied to the biological reactor is a key operational factor that affects these emissions. The operation of the activated sludge system at high values of SRT promotes endogenous respiration of biomass which increases the amount of COD oxidized to $\mathrm{CO}_{2}$ and decreases the overall sludge production. This decrease of sludge production implies a decrease of the methane production and, therefore, a decrease of the $\mathrm{CO}_{2}$ emissions associated with its combustion [38]. Both tendencies counteract each other and the addition value of both quantities remains almost constant. Furthermore, the decrease of the SRT also involves an increase of the energy efficiency of the WWTP and, therefore, a decrease of indirect $\mathrm{CO}_{2}$ emissions. Therefore, $\mathrm{CO}_{2}$ emissions should be minimized by applying the shortest SRT value as possible without negatively affecting the effluent quality.

The effect of SRT on the overall $\mathrm{CO}_{2}$ emissions of a conventional WWTP can be quantified by performing mass and energy balances according to the methodology described by Campos et al. [39] and using the parameters given in
TABLE 1: Values assigned to the parameters used to estimate $\mathrm{CO}_{2}$ emissions.

\begin{tabular}{lcc}
\hline Parameter & Units & Reference \\
\hline $\begin{array}{l}\mathrm{CO}_{2} \text { emissions from } \\
\text { energy consumption }\end{array}$ & $0.391 \mathrm{~kg} \mathrm{CO}_{2} / \mathrm{kW} \cdot \mathrm{h}$ & \\
$\mathrm{CO}_{2}$ emissions from & $0.08 \mathrm{~kg} \mathrm{CO}_{2} / \mathrm{kg} \mathrm{COD}^{*}$ & {$[40]$} \\
$\mathrm{COD}^{*}$ oxidation & & \\
$\mathrm{CO}_{2}$ emissions from & $3.5 \mathrm{~kg} \mathrm{CO}_{2} / \mathrm{Nm}^{3} \mathrm{CH}_{4}{ }^{* *}$ & \\
$\mathrm{CH}_{4}$ combustion & & \\
\hline
\end{tabular}

${ }^{*}$ Estimated taking into account an elemental composition of $\mathrm{C}_{2.43} \mathrm{H}_{3.96} \mathrm{O}$ for the biodegradable fractions of the COD [41]. ** Calculated from stoichiometry and ideal gas law.

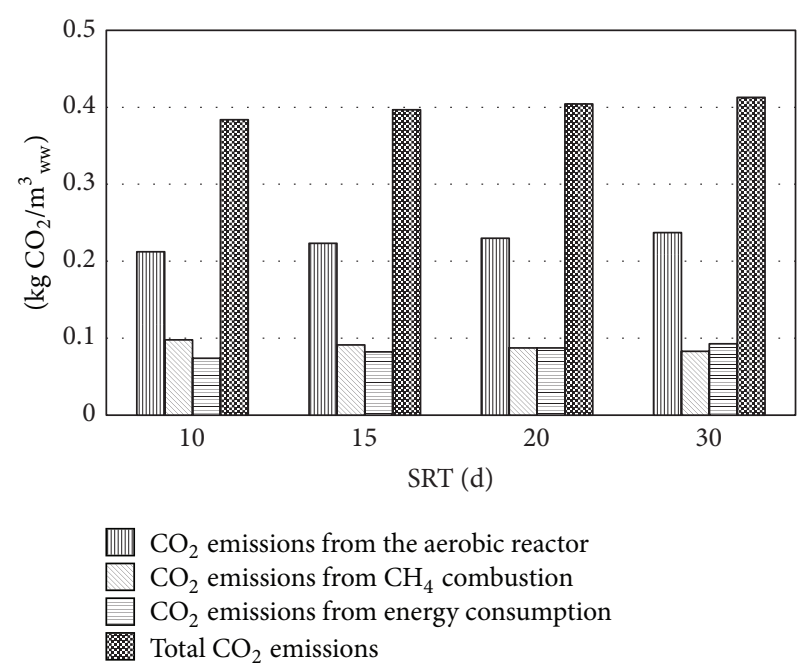

FIGURE 2: $\mathrm{CO}_{2}$ emissions estimated for a conventional WWTP operated at different SRT values.

Table 1 . The SRT values tested ranged from 10 to $30 \mathrm{~d}$ in order to guarantee a stable nitrification. Results showed that an increase of the SRT from 10 to 30 days supposed an increase of $7.6 \%$ of the $\mathrm{CO}_{2}$ emissions (Figure 2).

\section{Treatment}

A second possible option to reduce GHG emissions from WWTPs is to capture and treat them. An important number of technologies are available to destroy or capture $\mathrm{N}_{2} \mathrm{O}, \mathrm{CH}_{4}$, and $\mathrm{CO}_{2}$ from industrial gaseous streams but there is still a need for the development of efficient low-cost abatement technologies to treat gaseous streams from WWTPs. On the other hand, the capital costs required to cover the different tanks and capture GHG emissions are relatively high [47].

3.1. $\mathrm{N}_{2} \mathrm{O}$ Removal. Traditional technologies, such as selective catalytic reduction and selective noncatalytic reduction, are currently used to control $\mathrm{NO}_{x}$ emissions from power plants [48-50]. However, both processes require operating at high temperatures or using catalysts, which revert to high installation and maintenance costs. These total costs become prohibitive in large-scale facilities treating air flows containing low-to-moderate concentrations of $\mathrm{NO}_{x}$ [51]. Recently, 
many different bioprocesses, using nitrifying and denitrifying bacteria or microalgae, have been developed to control $\mathrm{NO}_{x}$ gas emissions. Technologies based on the denitrification process have been successfully used to remove $\mathrm{N}_{2} \mathrm{O}$ with efficiencies of 75-99\% [51-53]. However, the low aqueous solubility of this greenhouse gas limits the mass transfer rate from the air flow to the liquid phase and, therefore, high hydraulic retention times (HRT) are required to achieve high $\mathrm{N}_{2} \mathrm{O}$ removal efficiencies. These long applied HRT result in large bioscrubber (or biofilter) volumes, with the subsequent increase in capital costs [53]. Another alternative is to collect the outlet gaseous stream from the top of the nitrifying unit, containing $\mathrm{N}_{2} \mathrm{O}$, and use it as oxidizer to burn the methane produced in the anaerobic sludge digester [54].

3.2. $\mathrm{CH}_{4}$ Removal. Biological technologies to remove $\mathrm{CH}_{4}$ from waste gaseous emissions, based on biofilter systems, have been studied since the early 1990s although they are not yet consolidated at industrial scale $[55,56]$. Several biological processes are capable of oxidizing methane into $\mathrm{CO}_{2}(1 \mathrm{~mol}$ to $1 \mathrm{~mol}$ ) which allow reducing the total GHG emissions in terms of $\mathrm{CO}_{2}$ equivalents since the warming factor of $\mathrm{CO}_{2}$ is lower than that of methane. In aerobic conditions $\mathrm{CH}_{4}$ is oxidized by methanotrophic bacteria in the presence of oxygen. Another option relies on the application of anaerobic conditions and exploitation of the activity of bacteria and archaea to oxidize $\mathrm{CH}_{4}$ using sulfate, nitrite, nitrate, $\mathrm{Mn}^{+4}$, or $\mathrm{Fe}^{+3}$ as electron acceptors [57]:

$$
\begin{gathered}
\mathrm{CH}_{4}+\mathrm{SO}_{4}{ }^{-2} \longrightarrow \mathrm{HCO}_{3}{ }^{-}+\mathrm{HS}^{-}+\mathrm{H}_{2} \mathrm{O} \\
\Delta G=-16.6 \mathrm{~kJ} / \mathrm{mol} \\
3 \mathrm{CH}_{4}+8 \mathrm{NO}_{2}{ }^{-}+8 \mathrm{H}^{+} \longrightarrow 3 \mathrm{CO}_{2}+4 \mathrm{~N}_{2}+10 \mathrm{H}_{2} \mathrm{O} \\
\Delta G=-928 \mathrm{~kJ} / \mathrm{mol} \\
5 \mathrm{CH}_{4}+8 \mathrm{NO}_{3}{ }^{-}+8 \mathrm{H}^{+} \longrightarrow 5 \mathrm{CO}_{2}+4 \mathrm{~N}_{2}+14 \mathrm{H}_{2} \mathrm{O} \\
\Delta G=-765 \mathrm{~kJ} / \mathrm{mol} \\
\mathrm{CH}_{4}+4 \mathrm{MnO}_{2}+7 \mathrm{H}^{+} \longrightarrow \mathrm{HCO}_{3}{ }^{-}+4 \mathrm{Mn}^{+2}+5 \mathrm{H}{ }_{2} \mathrm{O} \\
\Delta G=-556 \mathrm{~kJ} / \mathrm{mol} \\
\mathrm{CH}_{4}+8 \mathrm{Fe}\left(\mathrm{OH}_{3}+15 \mathrm{H}^{+} \quad\right. \\
\longrightarrow \mathrm{HCO}_{3}{ }^{-}+8 \mathrm{Fe}^{+2}+21 \mathrm{H}_{2} \mathrm{O}
\end{gathered}
$$

As in the case of the $\mathrm{N}_{2} \mathrm{O}$ gas, the low solubility of $\mathrm{CH}_{4}$ implies the necessity to operate the biofilters at high residence time values (2-30 minutes) [58]. For these reasons, nowadays, the interest has moved to remove the $\mathrm{CH}_{4}$ directly from the liquid phase, before it is stripped to the atmosphere. To accomplish this removal the anaerobic methane oxidation is coupled to a denitrification process ((2)-(3)) which uses the methane as electron donor. In this case methane and both nitrite and nitrate are removed from wastewater [59]. Furthermore not only is the GHG removed but also the electron donor requirements for the denitrification processes diminish, reducing the costs of potential addition of external carbon source.

After the biological processes the methane remaining in the exhausted gaseous stream can be submitted to a postcombustion process [60].

3.3. $\mathrm{CO}_{2}$ Removal. For the $\mathrm{CO}_{2}$ gas removal extensive research has been carried out on the study of its capture by chemical or physical sorption and membrane separation processes from power cycles and industrial processes $[61,62]$. However, the application of these technologies is generally associated with high capital and operating costs and the generation of waste streams. For these reasons, nowadays the cultivation of microalgae is being considered as an attractive alternative for $\mathrm{CO}_{2}$ gas sequestration. In WWTPs microalgae can be used for precombustion $\mathrm{CO}_{2}$ capture, as an economic way for biogas purification [63], or for postcombustion $\mathrm{CO}_{2}$ capture in order to maximize the microalgae production for their use as biofertilizer [64] or as substrate to increase biogas production [65].

\section{Prevention}

Most of the efforts to improve WWTPs performance are being focused on economic aspects related to energy consumption reduction, minimization of sludge production, and maximization of the amount and quality of biogas generated. To face these topics is important not only in terms of operational costs but also in terms of environmental impacts since it allows reducing direct and indirect GHG emissions $[9,66,67]$.

Nowadays, only around $35-45 \%$ of the energy contained in the raw wastewater, as organic compounds, is converted into $\mathrm{CH}_{4}$ during anaerobic digestion of primary and secondary sludge. The remaining part is wasted under aerobic conditions due to the use of conventional nitrification and denitrification processes to remove nitrogen and organic matter simultaneously [68]. An alternative is to apply autotrophic processes to remove nitrogen, such as those based on the combination of the partial nitrification plus Anammox processes or the use of microalgae and even the application of biochemical processes. In this way both organic matter and nitrogen compounds can be removed in separated processes as the former is not required for denitrification but directed to the anaerobic digestion for biogas production. Thus oxygen requirements are minimized while methane production is maximized [69-71].

4.1. Application of Partial Nitritation and Anammox Processes to Remove Ammonia. In principle according to the metabolism of Anammox bacteria these are not directly involved in the production of $\mathrm{N}_{2} \mathrm{O}$ [72] and, therefore, the application of the Anammox process in the WWTPs instead of the conventional nitrification-denitrification processes is expected to reduce $\mathrm{N}_{2} \mathrm{O}$ emissions. However, in practice during the operation of full-scale Anammox reactors treating the reject water from sludge anaerobic digesters $\mathrm{N}_{2} \mathrm{O}$ emissions have been detected and accounted for up to $0.6 \%$ of 
the converted nitrogen [46]. This value is much higher than the percentages previously measured in lab-scale Anammox enriched reactors fed with synthetic media of $0.03-0.1 \%$ $[73,74]$. For this reason the results at full scale can be attributed to the presence of nitrifying bacteria, entering the Anammox reactor in the stream coming from the previous partial nitrification unit [74].

Furthermore Kampschreur et al. [46] measured also $\mathrm{N}_{2} \mathrm{O}$ emissions in a partial nitritation full-scale reactor, attributed to denitrification carried out by ammonia-oxidizing bacteria, which corresponded to the $1.7 \%$ of the inlet nitrogen load [18]. From the previous results, obtained from full-scale systems, about $2.3 \%$ of the nitrogen load can be converted to $\mathrm{N}_{2} \mathrm{O}$ in nitritation-Anammox systems. In these conditions a two-stage partial nitritation-Anammox process appears as a nonsuitable alternative to reduce $\mathrm{N}_{2} \mathrm{O}$ emissions in WWTPs $[66,67]$.

Emitted percentages can be reduced down to $0.8-1.2 \%$ if a one-reactor nitritation-Anammox system is used [43, 7577]. At full scale this configuration is the most applied one for the treatment of reject water from the sludge line [78]. For this reason, all the latest studies of the application at the main stream of the Anammox based processes have been carried out in single-stage systems. However, this kind of systems must be operated at low dissolved oxygen concentrations to maintain the balance between ammonia oxidation and Anammox rates and, therefore, the achieved nitrogen removal rates are relatively low [68]. However to operate at low dissolved oxygen levels promotes the development of nitrite-oxidizing bacteria and favours the oxidation of ammonia to nitrate instead of its desired conversion to $\mathrm{N}_{2}$ [78]. Due to this difficulty in avoiding the activity of the nitrite-oxidizing bacteria a change of concept has occurred and most of the research in course to implement the Anammox process at the main stream is focused on the two-stage reactor configuration. In this way operational strategies to avoid the development of nitrite-oxidizing bacteria, without affecting the Anammox bacteria, can be evaluated [68]. This might imply that the emissions of $\mathrm{N}_{2} \mathrm{O}$ would hamper the practical application of the partial nitritation-Anammox process, from the energy-saving and cost-effective point of view. Nevertheless, since the total amount of $\mathrm{N}_{2} \mathrm{O}$ emission from the partial nitrification unit is correlated to the nitrite concentration present, $\mathrm{N}_{2} \mathrm{O}$ emissions about $0.1 \%$ of the inlet nitrogen load are expected considering a nitritation unit operated for the treatment of the main stream (20$25 \mathrm{mg} \mathrm{NO}_{2}{ }^{-}-\mathrm{N} / \mathrm{L}$ ) [44]. Until now data of $\mathrm{N}_{2} \mathrm{O}$ emissions from Anammox systems in operation in the main stream conditions are not available in the literature, although if the entrance of nitrifying bacteria inside the Anammox system is minimized the expected emissions would be limited to $0.1 \%$ of the inlet nitrogen load and mainly due to the presence of heterotrophic denitrifying bacteria $[45,79]$. This means that the partial nitritation-Anammox system treating the main stream would emit in total around $0.2 \%$ of the inlet nitrogen load as $\mathrm{N}_{2} \mathrm{O}$.

Taking into account the fact that WWTPs with nitrogen removal carried out by nitrification-denitrification processes have a median emission factor of $0.01 \mathrm{~kg} \mathrm{~N} 2 \mathrm{O}-\mathrm{N} / \mathrm{kg} \mathrm{N} \mathrm{N}_{\text {influent }}$
[42], meaning that $0.6 \%$ of the inlet nitrogen is converted into $\mathrm{N}_{2} \mathrm{O}$, the application of partial nitritation-Anammox processes in both sludge line $(20 \%$ of the total nitrogen load with a conversion of $0.8 \%$ into $\mathrm{N}_{2} \mathrm{O}$ ) and main stream $(80 \%$ of the total nitrogen load with a conversion of $0.2 \%$ into $\mathrm{N}_{2} \mathrm{O}$ ) will signify an important decrease of the $\mathrm{N}_{2} \mathrm{O}$ emissions.

4.2. CANDO Process. Recently, Scherson et al. [54] introduced a new $\mathrm{N}$ removal process called CANDO (Coupled Aerobic-anoxic Nitrous Decomposition Operation) which involves three steps: (1) biological conversion of $\mathrm{NH}_{4}{ }^{+}$to $\mathrm{NO}_{2}{ }^{-}$; (2) biological or chemical partial anoxic reduction of $\mathrm{NO}_{2}{ }^{-}$to $\mathrm{N}_{2} \mathrm{O}$; and (3) $\mathrm{N}_{2} \mathrm{O}$ conversion to $\mathrm{N}_{2}$ with energy recovery.

Then from steps (1) and (2) ammonia is converted to $\mathrm{N}_{2} \mathrm{O}$, which is used in step (3) as a cooxidant for $\mathrm{CH}_{4}$ combustion or decomposed over a metal oxide catalyst to recover energy. The end product of the reaction is the $\mathrm{N}_{2}$. The innovation consists of utilizing $\mathrm{N}_{2} \mathrm{O}$ as a renewable energy source and reducing the requirements of organic matter which is consumed during denitrification. Combustion of $\mathrm{CH}_{4}$ with $\mathrm{N}_{2} \mathrm{O}$ releases roughly $30 \%$ more heat than using $\mathrm{O}_{2}\left((6)\right.$ and (7)) and mitigates the release of $\mathrm{N}_{2} \mathrm{O}$ to the atmosphere:

$$
\begin{array}{r}
\mathrm{CH}_{4}+4 \mathrm{~N}_{2} \mathrm{O} \longrightarrow \mathrm{CO}_{2}+2 \mathrm{H}_{2} \mathrm{O}+4 \mathrm{~N}_{2} \\
\Delta H=1219 \mathrm{~kJ} / \mathrm{mol} \mathrm{CH}_{4} \\
\mathrm{CH}_{4}+2 \mathrm{O}_{2} \longrightarrow \mathrm{CO}_{2}+2 \mathrm{H}_{2} \mathrm{O} \\
\Delta H=890 \mathrm{~kJ} / \mathrm{mol} \mathrm{CH}_{4}
\end{array}
$$

Steps (1) and (3) of the CANDO process have been already applied at full scale while step (2) is still under study [54, $71,80]$. In these research works, two ways of producing nitrous oxide from nitrite are proposed: (1) abiotic reduction by $\mathrm{Fe}(\mathrm{II})$ with conversions over $90 \%$ and (2) partial heterotrophic denitrification ( $62 \%$ of $\mathrm{NO}_{2}{ }^{-}$converted to $\mathrm{N}_{2} \mathrm{O}$ ).

4.3. Application of Microalgae. One of the main operating costs of conventional activated sludge systems, where nitrogen removal takes place, is associated with the large aeration requirements. Alternative systems like those based on microalgae are being considered as potential substitutes. In these systems nitrogen is removed via assimilation for biomass growth without oxygen consumption (8) [81], decreasing energy requirements. Moreover, a low $\mathrm{N}_{2} \mathrm{O}$ production is expected $\left(0.005 \% \mathrm{~kg} \mathrm{~N} \mathrm{~N}_{2} \mathrm{O}-\mathrm{N} / \mathrm{kg} \mathrm{N} \mathrm{N}_{\text {applied }}\right)$ if microalgae are used to remove nitrogen [82]

$$
\begin{aligned}
& 106 \mathrm{CO}_{2}+236 \mathrm{H}_{2} \mathrm{O}+16 \mathrm{NH}_{4}^{+}+\mathrm{HPO}_{4}{ }^{-2}+\text { light } \\
& \longrightarrow \mathrm{C}_{106} \mathrm{H}_{181} \mathrm{O}_{45} \mathrm{~N}_{16} \mathrm{P}+118 \mathrm{O}_{2}+171 \mathrm{H}_{2} \mathrm{O}+14 \mathrm{H}^{+}
\end{aligned}
$$

When microalgae are applied for wastewater treatment cultivation the process is generally carried out in open raceway ponds, since the capital costs of these systems are lower than those of photobioreactors [83]. These microalgae ponds occupy large land areas which limits their use to rural areas. 


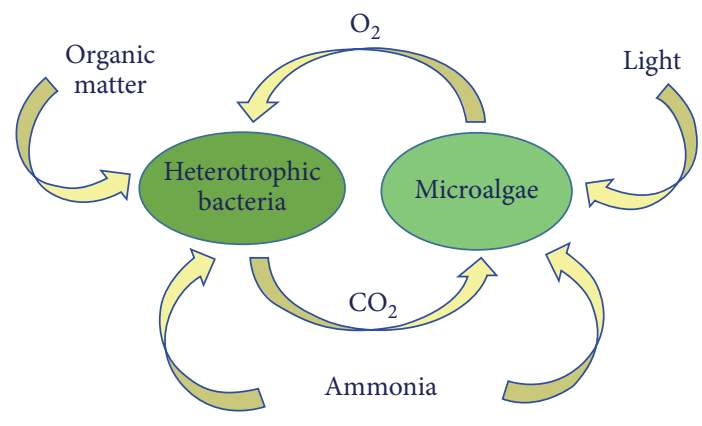

FIGURE 3: Interactions of a mix culture containing heterotrophic bacteria and microalgae.

Another disadvantage of the microalgae application relies on the poor settling properties of the microalgae, which implies the use of coagulants and flocculants for separation from the treated wastewater [84]. For this reason, a novel approach consisting in the use of algal-bacterial cocultures has received significant attention in recent years as well. In this way the bacterial population would profit from the $\mathrm{O}_{2}$ produced by algae reducing the aeration requirements of treatment processes and at the same time greenhouse gas emissions are mitigated by the $\mathrm{CO}_{2}$ consumption during algal photosynthesis (Figure 3). According to (8), microalgae produce $17 \mathrm{~kg} \mathrm{O}_{2} / \mathrm{kg} \mathrm{N}_{\text {removed }}$. Then, for typical urban wastewater, the amount of oxygen produced by microalgae would be higher than the $\mathrm{O}_{2}$ amount needed to remove organic matter by the activity of the heterotrophic biomass [85]. Therefore, both organic matter and nitrogen could be simultaneously removed in an open raceway pond without oxygen external supply. In addition, challenges associated with the high energy requirements for algal biomass harvesting might be overcome by means of the better settleability properties of the algal-bacterial coculture. Su et al. [86] demonstrated that an algal-bacterial coculture is able not only to achieve high COD and nutrient removal efficiencies but also to settle completely over 20 minutes. They also argued that the shares of algae and sludge inoculated in the pond have an influence on the nutrient removal efficiency and settleability, and they identify the ratio value of $1: 5$ (algae/sludge by weight) as that providing the biomass with the best settleability.

\section{Case Studies}

In order to quantify the potential reduction of GHG emissions due to the implementation of new processes in WWTPs (prevention strategy), five different configurations were evaluated for comparison purposes.

Case A. A conventional activated sludge system was used as a base case, performing the nitrification-denitrification process to remove both organic matter and nitrogen (Figure 4). The operational conditions of this system were SRT of $15 \mathrm{~d}$, hydraulic retention time (HRT) of $12 \mathrm{~h}$, internal recycle ratio of 3 , external recycle ratio of 1 , and aerobic volume percentage of $45 \%$. In the primary settler, a particulate COD removal efficiency of $45 \%$ was assumed. Primary and secondary sludge are treated in an anaerobic digester (SRT: $30 \mathrm{~d}$ ) in order to produce biogas, used in a cogeneration unit, and reduce the amount of sludge generated. The following cases take this one as a base case and only the descriptions of modifications applied to this configuration are included.

Case $B$. The activated sludge system was substituted by an aerobic reactor operated at a SRT of $2 \mathrm{~d}$, to remove organic matter and to maximize the sludge generation, in order to increase methane production, followed by a partial nitritation and an Anammox reactor to remove nitrogen. In this case, the primary settler is intended for removing all the particulate $\mathrm{COD}$ to promote the anaerobic route of organic matter. Nitrogen is treated from the return sludge stream by a 1-stage partial nitritation-Anammox reactor.

Case C. A CANDO system comprising a partial nitrification and a partial denitrifying reactor is implemented in the sludge line. In this case, organic matter separated in the primary sludge is increased $20 \%$ since the nitrogen load applied to the activated sludge system is decreased in the same percentage. In the sludge line, an acidogenic reactor is used to provide organic matter to the partial denitrifying reactor. Produced $\mathrm{N}_{2} \mathrm{O}$ is used, instead of $\mathrm{O}_{2}$, to burn methane.

Case $D$. The activated sludge system was substituted by an aerobic reactor operated at a SRT of $2 \mathrm{~d}$, to remove organic matter, followed by a high rate microalgae pond, operated at a HRT of 6 days, to remove nitrogen.

Case E. A high rate microalgae pond (SRT and HRT of 6 days) where the microalgae remove the nitrogen and provide the oxygen required for the heterotrophic bacteria to oxidize the organic matter was evaluated in substitution of the activated sludge system.

Mass and energy balances were performed by using Excel spreadsheets according to the methodology described in Campos et al. [39]. Finally, the emissions of $\mathrm{CO}_{2}, \mathrm{CH}_{4}$, and $\mathrm{N}_{2} \mathrm{O}$ were estimated considering the results obtained from the mass balances and the parameters given in Tables 1 and 2. From these values the global GHG emissions of each configuration expressed as $\mathrm{kg} \mathrm{CO}_{2} / \mathrm{m}^{3}$ of wastewater treated were calculated taking into account the greenhouse gas production impact factors of 21 and 310 for $\mathrm{CH}_{4}$ and $\mathrm{N}_{2} \mathrm{O}$, respectively.

Results obtained from the calculations indicate that systems using microalgae to remove nitrogen are the most suitable systems to reduce GHG emissions during wastewater treatment (Figure 5). This fact is mainly due to the high amount of $\mathrm{CO}_{2}$ captured by the microalgae together with the contribution of three other factors: (1) the improvement of the WWTP energy efficiency: in Case D, since the application of microalgae to remove nitrogen does not require the presence of organic matter, most of it can be converted into methane while, in Case E, oxygen generated by microalgae allows an important energy saving in terms of aeration; (2) the very low emissions of $\mathrm{N}_{2} \mathrm{O}$ observed in the high rate microalgae ponds; and (3) the additional biogas production due to the anaerobic digestion of the generated microalgae. 
Case A

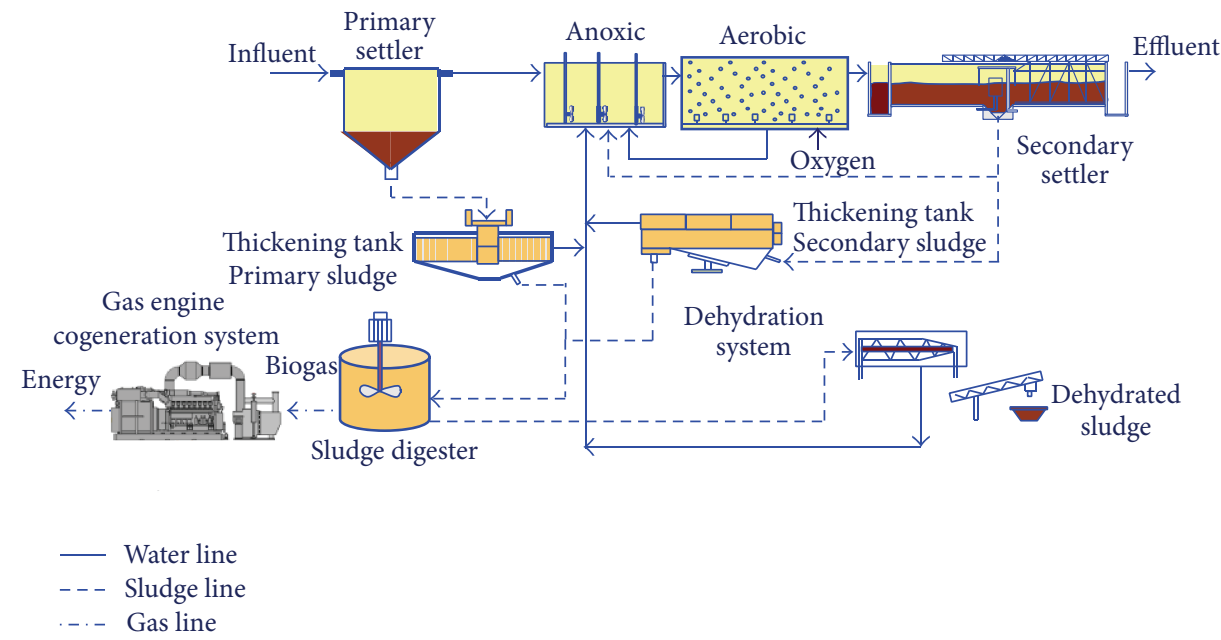

Case B

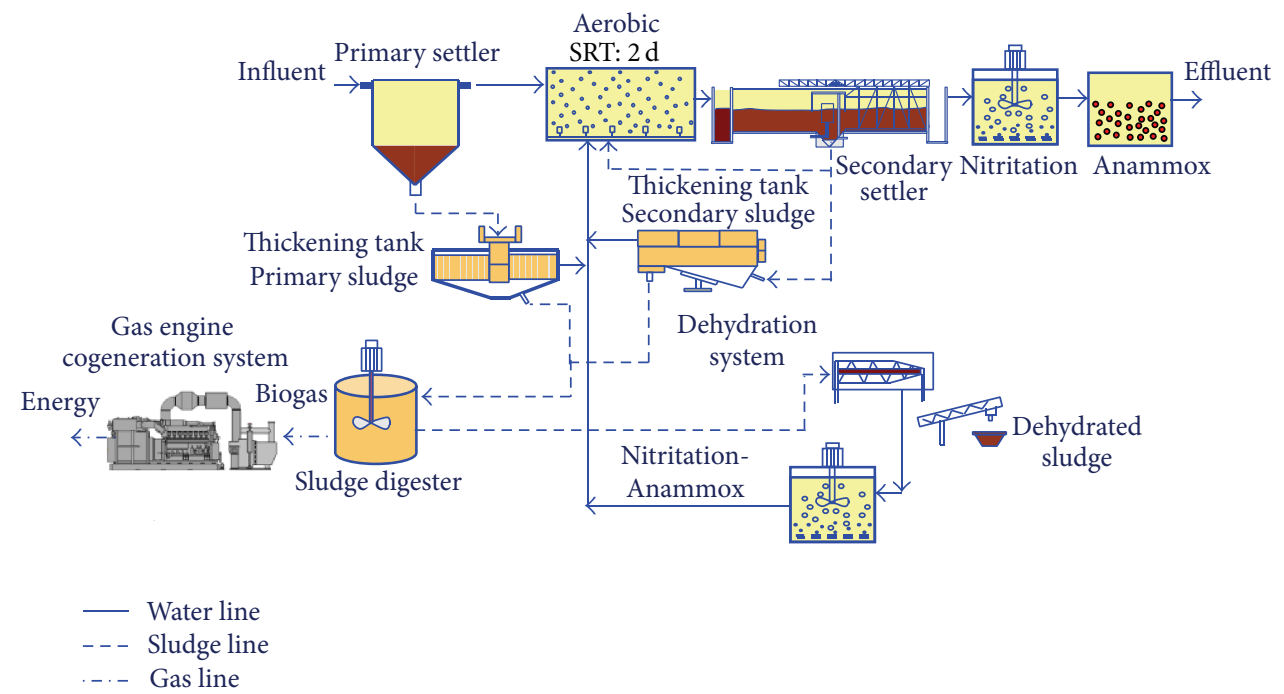

Case C

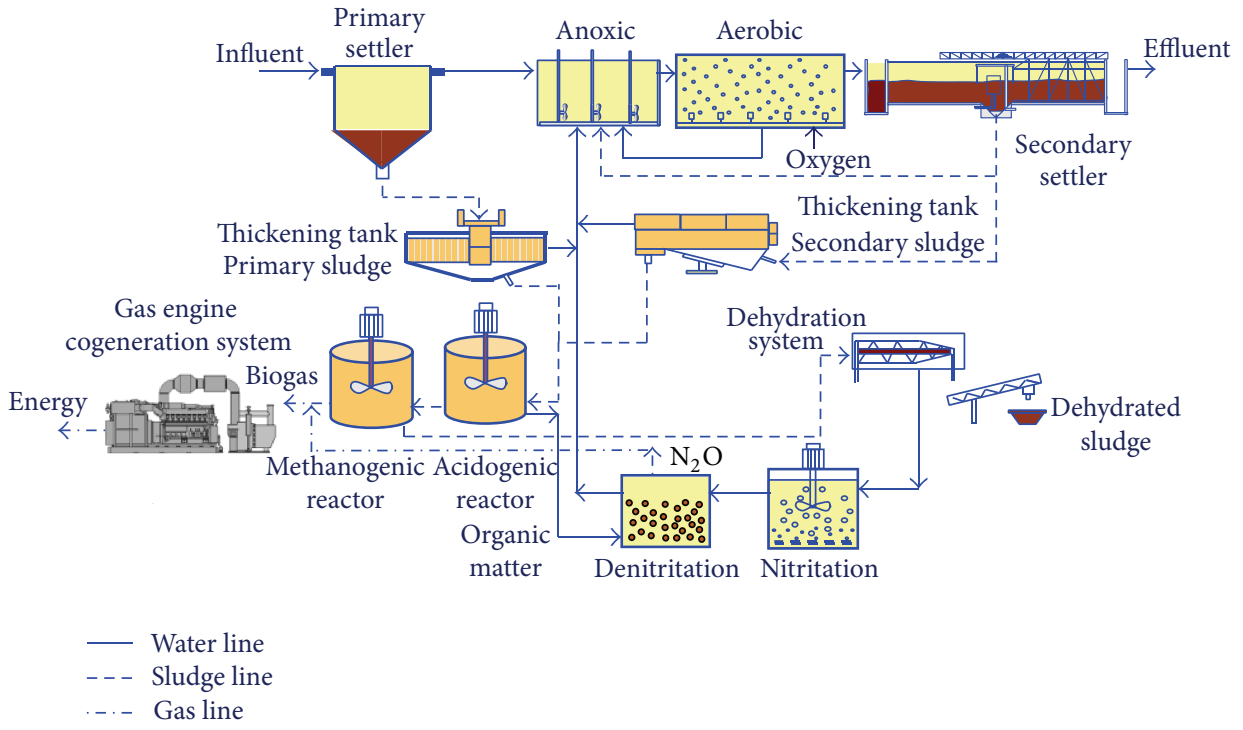

FIgURE 4: Continued. 

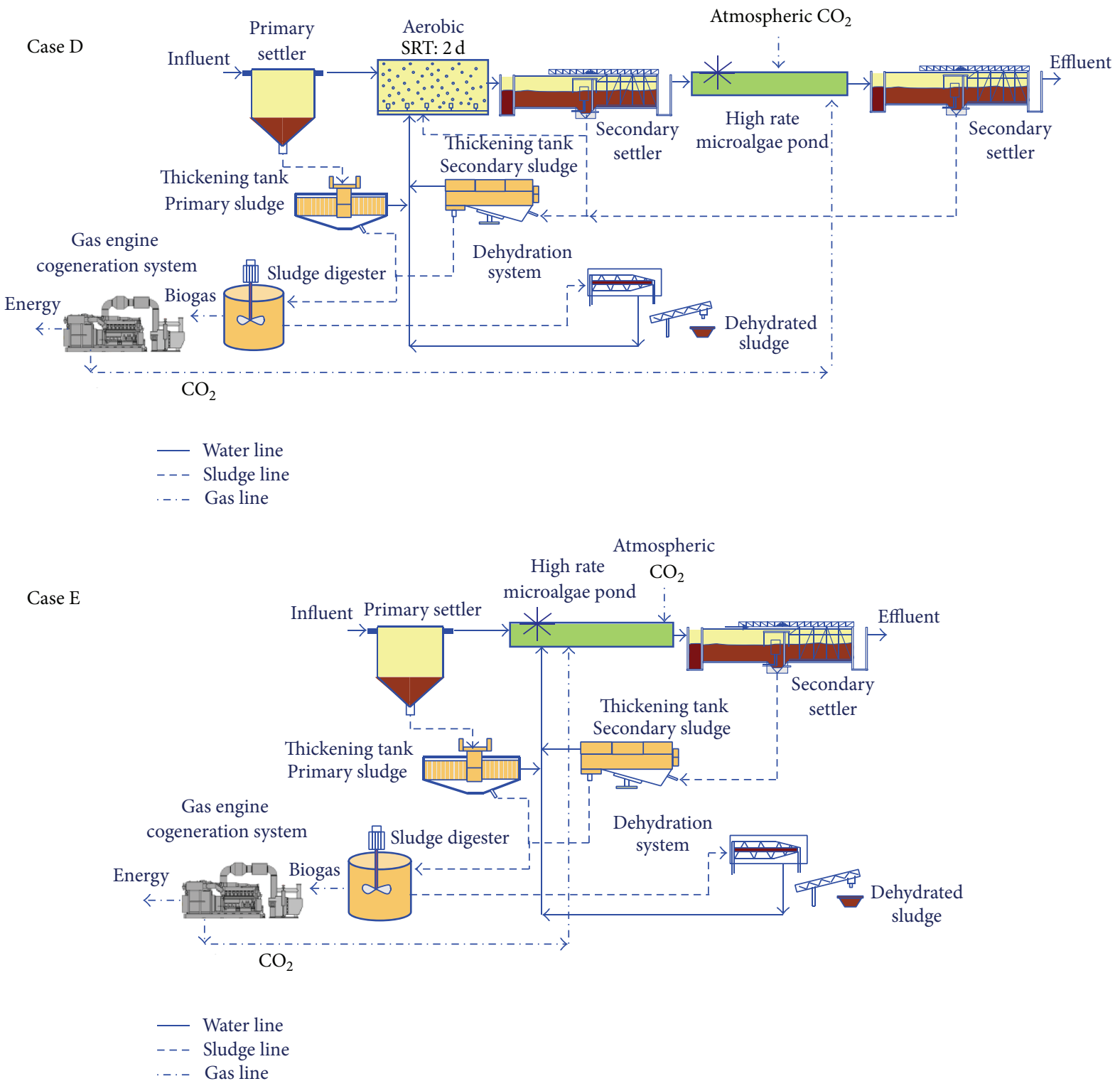

Figure 4: Layout of the five WWTPs configurations evaluated in terms of GHG emissions.

TABLE 2: Values assigned to the parameters used to estimate GHG emissions for the case studies.

\begin{tabular}{ll}
\hline Parameter & Units \\
\hline $\mathrm{CH}_{4}$ emissions from leakages & $0.85 \%$ of COD treated $+1.3 \%$ of $\mathrm{CH}_{4}$ burnt $^{*}$ \\
$\begin{array}{l}\mathrm{N}_{2} \mathrm{O} \text { emissions from nitrification-denitrification } \\
\text { units }\end{array}$ & $0.5 \%$ of the nitrogen treated \\
$\begin{array}{l}\mathrm{N}_{2} \mathrm{O} \text { emissions from 1-stage partial } \\
\text { nitritation-Anammox reactors (sludge line) }\end{array}$ & $0.8 \%$ of the nitrogen treated \\
$\mathrm{N}_{2} \mathrm{O}$ emissions from PN reactor (main stream) & $0.1 \%$ of the nitrogen treated \\
$\begin{array}{l}\mathrm{N}_{2} \mathrm{O} \text { emissions from Anammox reactor (main } \\
\text { stream) }\end{array}$ & $0.1 \%$ of the nitrogen treated \\
$\mathrm{N}_{2} \mathrm{O}$ emissions from CANDO process & $3.4 \%$ of the nitrogen treated $+1.3 \%$ of $\mathrm{N}_{2} \mathrm{O}$ burnt $^{* *}$
\end{tabular}

${ }^{*}$ Taking into account the fact that $\mathrm{CH}_{4}$ leakage from the cogeneration engine is $15 \%$ of the $\mathrm{CH}_{4}$ emissions. ${ }^{* *}$ Taking into account the fact that all the ammonia present in the wastewater is converted into nitrite in the partial nitrification reactor and supposing a leakage of the $\mathrm{N}_{2} \mathrm{O}$ from the cogeneration engine similar to that of the $\mathrm{CH}_{4}$. 


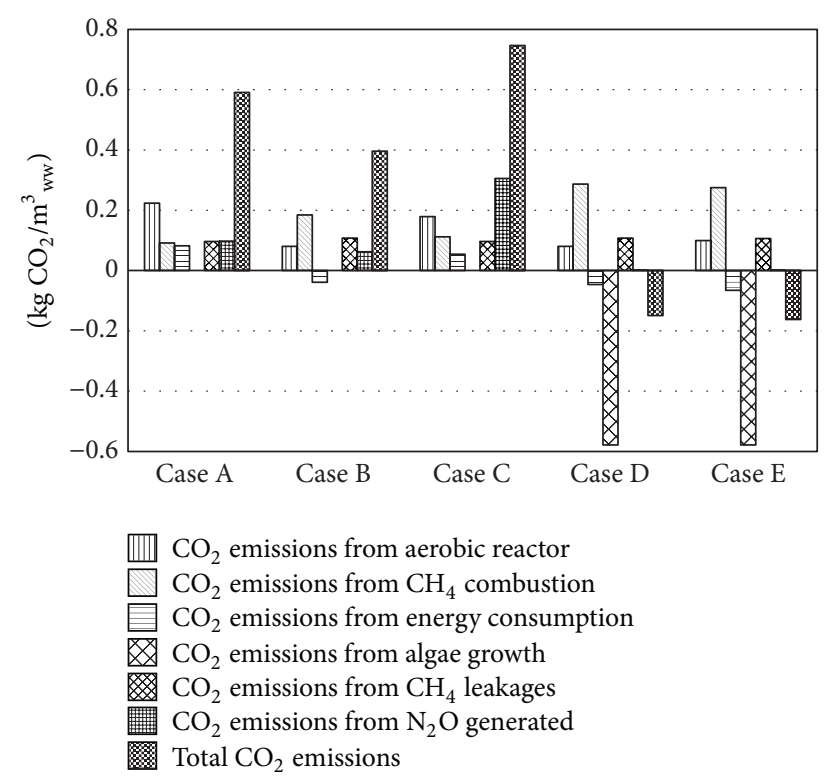

FIGURE 5: GHG emissions (expressed as $\mathrm{kg} \mathrm{CO}_{2}$, equivalent $/ \mathrm{m}^{3}$ of wastewater treated) of different WWTPs configurations.

When the partial nitritation and Anammox processes are used to remove ammonia, instead of conventional nitrification and denitrification processes, the WWTP energy efficiency is also improved which also causes a decrease of GHG emissions. However this decrease is considerably lower than that obtained by microalgae systems.

The WWTP configuration based on the application of the CANDO process (Case C) has associated GHG emissions higher than those of the conventional system. This can be attributed to the increase of $\mathrm{N}_{2} \mathrm{O}$ emissions due to the implementation of a partial nitrification reactor in the sludge line and the leakage of nitrous oxide expected in the exhaust gas. On the other hand, in this process organic matter is used to denitrify nitrite into $\mathrm{N}_{2} \mathrm{O}$, decreasing methane production, while $\mathrm{N}_{2} \mathrm{O}$ generated can be used to oxidize only around $8 \%$ of methane. Those factors limit the energy efficiency improvement achieved by the application of CANDO process.

Nowadays, there are several technologies already implemented at full scale to perform partial nitrification-Anammox processes in the sludge line $[87,88]$. However, in spite of the recent advances, their implementation at the main stream is still a challenge due to the strict control of operational conditions needed to maintain the stability of the partial nitrification process [89]. The use of microalgae systems to remove nitrogen from domestic wastewater is a feasible option when enough land is available since this kind of systems would require about ten times the area necessary for activated sludge systems [90]. The CANDO process can be used to improve energy efficiency of WWTPs but can only be applied to the sludge line. Moreover, the need of the development of a reliable technology for its implementation at full scale and its negative environmental impact make it not as attractive as the partial nitrification-Anammox and microalgae systems.

\section{Conclusions}

Minimization. $\mathrm{N}_{2} \mathrm{O}$ and $\mathrm{CO}_{2}$ emissions can be decreased by a good control of the operational conditions of the activated sludge system. $\mathrm{CH}_{4}$ emissions can be minimized if emissions from the different units of the sludge line are captured by hoods and burnt together with the biogas generated in the sludge anaerobic digester. $\mathrm{N}_{2} \mathrm{O}$ emissions will depend mainly on the operational conditions $\left(\mathrm{NO}_{2}{ }^{-}\right.$and $\mathrm{O}_{2}$ concentrations) of the reactor systems.

Treatment. Nowadays most of the technologies available to remove GHG are expensive or even not suitable to be applied to gaseous streams of the WWTPs. Biological systems treatment has low operating costs but their capital costs are high due to their size. The correct selection of the process to be installed in the plant will provide the best results as it is the case of the partial nitritation-Anammox process which is feasible in two units applied in the main stream of the plant but not for the treatment of the sludge line.

Prevention. The configuration of the next generation of WWTPs should maximize the anaerobic pathway for organic matter removal and the use of microalgae, if enough area is available, or partial nitritation-Anammox processes to remove ammonia.

\section{Competing Interests}

The authors declare that they have no competing interests.

\section{Acknowledgments}

This work was supported by FONDECYT 1150285 (Chile) and Postdoctoral FONDECYT 3140276 (Chile) and by the Spanish Government through FISHPOL (CTQ2014-55021-R) and GRANDSEA (CTM2014-55397-JIN) projects cofunded by FEDER. The authors A. Pedrouso, A. Val del Río, and A. Mosquera-Corral belong to the Galician Competitive Research Group GRC 2013-032, program cofunded by FEDER.

\section{References}

[1] N. Bolong, A. F. Ismail, M. R. Salim, and T. Matsuura, "A review of the effects of emerging contaminants in wastewater and options for their removal," Desalination, vol. 238, no. 1-3, pp. 229-246, 2009.

[2] L. Zanetti, N. Frison, E. Nota, M. Tomizioli, D. Bolzonella, and F. Fatone, "Progress in real-time control applied to biological nitrogen removal from wastewater. A short-review," Desalination, vol. 286, pp. 1-7, 2012.

[3] W. Luo, F. I. Hai, W. E. Price et al., "High retention membrane bioreactors: challenges and opportunities," Bioresource Technology, vol. 167, pp. 539-546, 2014.

[4] A. Santos, W. Ma, and S. J. Judd, "Membrane bioreactors: two decades of research and implementation," Desalination, vol. 273, no. 1, pp. 148-154, 2011. 
[5] Q. Zhang, J. Hu, and D. J. Lee, "Aerobic granular processes: current research trends," Bioresource Technology, vol. 210, pp. 74-80, 2016.

[6] W. Mo and Q. Zhang, "Energy-nutrients-water nexus: integrated resource recovery in municipal wastewater treatment plants," Journal of Environmental Management, vol. 127, pp. 255267, 2013.

[7] L. Yerushalmi, O. Ashrafi, and F. Haghighat, "Reductions in greenhouse gas (GHG) generation and energy consumption in wastewater treatment plants," Water Science and Technology, vol. 67, no. 5, pp. 1159-1164, 2013.

[8] M. Bani Shahabadi, L. Yerushalmi, and F. Haghighat, "Impact of process design on greenhouse gas (GHG) generation by wastewater treatment plants," Water Research, vol. 43, no. 10, pp. 2679-2687, 2009.

[9] T. A. Larsen, " $\mathrm{CO}_{2}$-neutral wastewater treatment plants or robust, climate-friendly wastewater management? A systems perspective," Water Research, vol. 87, pp. 513-521, 2015.

[10] C. Sweetapple, G. Fu, and D. Butler, "Identifying sensitive sources and key control handles for the reduction of greenhouse gas emissions from wastewater treatment," Water Research, vol. 62, pp. 249-259, 2014.

[11] P. Czepiel, P. Crill, and R. Harriss, "Nitrous oxide emissions from municipal wastewater treatment," Environmental Science \& Technology, vol. 29, no. 9, pp. 2352-2356, 1995.

[12] M. J. Kampschreur, H. Temmink, R. Kleerebezem, M. S. M. Jetten, and M. C. M. van Loosdrecht, "Nitrous oxide emission during wastewater treatment," Water Research, vol. 43, no. 17, pp. 4093-4103, 2009.

[13] Y. Law, L. Ye, Y. Pan, and Z. Yuan, "Nitrous oxide emissions from wastewater treatment processes," Philosophical Transactions of the Royal Society B: Biological Sciences, vol. 367, no. 1593, pp. 1265-1277, 2012.

[14] J. Desloover, S. E. Vlaeminck, P. Clauwaert, W. Verstraete, and $\mathrm{N}$. Boon, "Strategies to mitigate $\mathrm{N}_{2} \mathrm{O}$ emissions from biological nitrogen removal systems," Current Opinion in Biotechnology, vol. 23, no. 3, pp. 474-482, 2012.

[15] J. L. Campos, B. Arrojo, J. R. Vázquez-Padín, A. MosqueraCorral, and R. Méndez, " $\mathrm{N}_{2} \mathrm{O}$ production by nitrifying biomass under anoxic and aerobic conditions," Applied Biochemistry and Biotechnology, vol. 152, no. 2, pp. 189-198, 2009.

[16] A. Soler-Jofra, B. Stevens, M. Hoekstra et al., "Importance of abiotic hydroxylamine conversion on nitrous oxide emissions during nitritation of reject water," Chemical Engineering Journal, vol. 287, pp. 720-726, 2016.

[17] J. H. Ahn, S. Kim, H. Park, B. Rahm, K. Pagilla, and K. Chandran, " $\mathrm{N}_{2} \mathrm{O}$ emissions from activated sludge processes, 20082009: results of a national monitoring survey in the United States," Environmental Science \& Technology, vol. 44, no. 12, pp. 4505-4511, 2010.

[18] C. M. Castro-Barros, M. R. J. Daelman, K. E. Mampaey, M. C. M. van Loosdrecht, and E. I. P. Volcke, "Effect of aeration regime on $\mathrm{N}_{2} \mathrm{O}$ emission from partial nitritation-anammox in a fullscale granular sludge reactor," Water Research, vol. 68, pp. 793803, 2015.

[19] P. Wunderlin, J. Mohn, A. Joss, L. Emmenegger, and H. Siegrist, "Mechanisms of $\mathrm{N}_{2} \mathrm{O}$ production in biological wastewater treatment under nitrifying and denitrifying conditions," Water Research, vol. 46, no. 4, pp. 1027-1037, 2012.

[20] G. Tallec, J. Garnier, G. Billen, and M. Gousailles, "Nitrous oxide emissions from secondary activated sludge in nitrifying conditions of urban wastewater treatment plants: effect of oxygenation level," Water Research, vol. 40, no. 15, pp. 29722980, 2006.

[21] M. R. J. Daelman, E. M. van Voorthuizen, U. G. J. M. van Dongen, E. I. P. Volcke, and M. C. M. van Loosdrecht, "Methane emission during municipal wastewater treatment," Water Research, vol. 46, no. 11, pp. 3657-3670, 2012.

[22] C. E. Yver Kwok, D. Müller, C. Caldow et al., "Methane emission estimates using chamber and tracer release experiments for a municipal waste water treatment plant," Atmospheric Measurement Techniques, vol. 8, no. 7, pp. 2853-2867, 2015.

[23] K. Oshita, T. Okumura, M. Takaoka, T. Fujimori, L. Appels, and R. Dewil, "Methane and nitrous oxide emissions following anaerobic digestion of sludge in Japanese sewage treatment facilities," Bioresource Technology, vol. 171, no. 1, pp. 175-181, 2014.

[24] D. Gupta and S. K. Singh, "Greenhouse gas emissions from wastewater treatment plants: a case study of Noida," Journal of Water Sustainability, vol. 2, no. 2, pp. 131-139, 2012.

[25] H. Yoshida, J. Mønster, and C. Scheutz, "Plant-integrated measurement of greenhouse gas emissions from a municipal wastewater treatment plant," Water Research, vol. 61, pp. 108118, 2014.

[26] D. Kyung, M. Kim, J. Chang, and W. Lee, "Estimation of greenhouse gas emissions from a hybrid wastewater treatment plant," Journal of Cleaner Production, vol. 95, pp. 117-123, 2015.

[27] M. Molinos-Senante, F. Hernández-Sancho, M. Mocholí-Arce, and R. Sala-Garrido, "Economic and environmental performance of wastewater treatment plants: potential reductions in greenhouse gases emissions," Resource and Energy Economics, vol. 38, pp. 125-140, 2014.

[28] A. Rodriguez-Caballero, I. Aymerich, M. Poch, and M. Pijuan, "Evaluation of process conditions triggering emissions of greenhouse gases from a biological wastewater treatment system," Science of the Total Environment, vol. 493, pp. 384-391, 2014.

[29] H. Bozkurt, M. C. van Loosdrecht, K. V. Gernaey, and G. Sin, "Optimal WWTP process selection for treatment of domestic wastewater-a realistic full-scale retrofitting study," Chemical Engineering Journal, vol. 286, pp. 447-458, 2016.

[30] A. Mahdy, L. Méndez, M. Ballesteros, and C. González-Fernández, "Algaculture integration in conventional wastewater treatment plants: anaerobic digestion comparison of primary and secondary sludge with microalgae biomass," Bioresource Technology, vol. 184, pp. 236-244, 2015.

[31] Y. D. Scherson and C. S. Criddle, "Recovery of freshwater from wastewater: upgrading process configurations to maximize energy recovery and minimize residuals," Environmental Science and Technology, vol. 48, no. 15, pp. 8420-8432, 2014.

[32] W. Dai, X. Xu, B. Liu, and F. Yang, "Toward energy-neutral wastewater treatment: a membrane combined process of anaerobic digestion and nitritation-anammox for biogas recovery and nitrogen removal," Chemical Engineering Journal, vol. 279, pp. 725-734, 2015.

[33] T. Schaubroeck, H. De Clippeleir, N. Weissenbacher et al., "Environmental sustainability of an energy self-sufficient sewage treatment plant: improvements through DEMON and co-digestion," Water Research, vol. 74, pp. 166-179, 2015.

[34] A. B. Bisinella de Faria, M. Spérandio, A. Ahmadi, and L. TirutaBarna, "Evaluation of new alternatives in wastewater treatment plants based on dynamic modelling and life cycle assessment (DM-LCA)," Water Research, vol. 84, pp. 99-111, 2015. 
[35] X. Hao, R. Liu, and X. Huang, "Evaluation of the potential for operating carbon neutral WWTPs in China," Water Research, vol. 87, pp. 424-431, 2015.

[36] M. Hauck, F. A. Maalcke-Luesken, M. S. Jetten, and M. A. Huijbregts, "Removing nitrogen from wastewater with side stream anammox: what are the trade-offs between environmental impacts?" Resources, Conservation and Recycling, vol. 107, pp. 212-219, 2016.

[37] Y. Law, P. Lant, and Z. Yuan, "The effect of $\mathrm{pH}$ on $\mathrm{N}_{2} \mathrm{O}$ production under aerobic conditions in a partial nitritation system," Water Research, vol. 45, no. 18, pp. 5934-5944, 2011.

[38] H. Ge, D. J. Batstone, and J. Keller, "Operating aerobic wastewater treatment at very short sludge ages enables treatment and energy recovery through anaerobic sludge digestion," Water Research, vol. 47, no. 17, pp. 6546-6557, 2013.

[39] J. L. Campos, A. Mosquera-Corral, A. Val del Río et al., "Energy and resources recovery in wastewater treatment plants," in Environmental Science \& Engineering, vol. 9 of Environmental and Energy Management: Ethics, Laws and Policies, pp. 60-78, Studium Press, 2015.

[40] P. Atkins, D. Colbourne, M. Dieryckx et al., "Methologies," in Safeguarding the Ozone Layer and the Global Climate System: Issues Related to Hydrofluorocarbons and Perfluorocarbons, B. Metz, L. Kuijpers, S. Solomon et al., Eds., Cambridge University Press, Cambridge, UK, 2005.

[41] I. Takács and P. A. Vanrolleghem, "Elemental balances in activated sludge modelling," in Proceedings of the International Water Association Congress (IWA '06), Beijing, China, 2006.

[42] J. Foley, D. de Haas, Z. Yuan, and P. Lant, "Nitrous oxide generation in full-scale biological nutrient removal wastewater treatment plants," Water Research, vol. 44, no. 3, pp. 831-844, 2010.

[43] S. Wyffels, P. Boeckx, K. Pynaert et al., "Nitrogen removal from sludge reject water by a two-stage oxygen-limited autotrophic nitrification denitrification process," Water Science and Technology, vol. 49, no. 5-6, pp. 57-64, 2004.

[44] C. M. Castro-Barros, A. Rodríguez-Caballero, E. I. P. Volcke, and M. Pijuan, "Effect of nitrite on the $\mathrm{N}_{2} \mathrm{O}$ and NO production on the nitrification of low-strength ammonium wastewater," Chemical Engineering Journal, vol. 287, pp. 269-276, 2016.

[45] S. Okabe, M. Oshiki, Y. Takahashi, and H. Satoh, " $\mathrm{N}_{2} \mathrm{O}$ emission from a partial nitrification-anammox process and identification of a key biological process of $\mathrm{N}_{2} \mathrm{O}$ emission from anammox granules," Water Research, vol. 45, no. 19, pp. 6461-6470, 2011.

[46] M. J. Kampschreur, W. R. L. van der Star, H. A. Wielders, J. W. Mulder, M. S. M. Jetten, and M. C. M. van Loosdrecht, "Dynamics of nitric oxide and nitrous oxide emission during full-scale reject water treatment," Water Research, vol. 42, no. 3 , pp. 812-826, 2008.

[47] M.-S. Chou and W.-H. Cheng, "Gaseous emissions and control in wastewater treatment plants," Environmental Engineering Science, vol. 22, no. 5, pp. 591-600, 2005.

[48] K. Skalska, J. S. Miller, and S. Ledakowicz, "Trends in NOx abatement: a review," Science of the Total Environment, vol. 408, no. 19, pp. 3976-3989, 2010.

[49] M. Konsolakis, "Recent advances on nitrous oxide $\left(\mathrm{N}_{2} \mathrm{O}\right)$ decomposition over non-noble-metal oxide catalysts: catalytic performance, mechanistic considerations, and surface chemistry aspects," ACS Catalysis, vol. 5, no. 11, pp. 6397-6421, 2015.

[50] F. Kapteijn, J. Rodriguez-Mirasol, and J. A. Moulijn, "Heterogeneous catalytic decomposition of nitrous oxide," Applied Catalysis B: Environmental, vol. 9, no. 1-4, pp. 25-64, 1996.
[51] Y. Jin, M. C. Veiga, and C. Kennes, "Bioprocesses for the removal of nitrogen oxides from polluted air," Journal of Chemical Technology \& Biotechnology, vol. 80, no. 5, pp. 483-494, 2005.

[52] O. D. Frutos, I. A. Arvelo, R. Pérez, G. Quijano, and R. Muñoz, "Continuous nitrous oxide abatement in a novel denitrifying off-gas bioscrubber," Applied Microbiology and Biotechnology, vol. 99, no. 8, pp. 3695-3706, 2015.

[53] O. D. Frutos, G. Quijano, R. Pérez, and R. Muñoz, "Simultaneous biological nitrous oxide abatement and wastewater treatment in a denitrifying off-gas bioscrubber," Chemical Engineering Journal, vol. 288, pp. 28-37, 2016.

[54] Y. D. Scherson, G. F. Wells, S.-G. Woo et al., "Nitrogen removal with energy recovery through $\mathrm{N}_{2} \mathrm{O}$ decomposition," Energy \& Environmental Science, vol. 6, no. 1, pp. 241-248, 2013.

[55] J. Nikiema, R. Brzezinski, and M. Heitz, "Elimination of methane generated from landfills by biofiltration: a review," Reviews in Environmental Science and Bio/Technology, vol. 6, no. 4, pp. 261-284, 2007.

[56] M. F. M. Abushammala, N. E. A. Basri, D. Irwan, and M. K. Younes, "Methane oxidation in landfill cover soils: a review," Asian Journal of Atmospheric Environment, vol. 8, no. 1, pp. 114, 2014.

[57] M. Cui, A. Ma, H. Qi, X. Zhuang, and G. Zhuang, "Anaerobic oxidation of methane: an 'active' microbial process," MicrobiologyOpen, vol. 4, no. 1, pp. 1-11, 2015.

[58] M. Veillette, M. Girard, P. Viens, R. Brzezinski, and M. Heitz, "Function and limits of biofilters for the removal of methane in exhaust gases from the pig industry," Applied Microbiology and Biotechnology, vol. 94, no. 3, pp. 601-611, 2012.

[59] J. Zhu, Q. Wang, M. Yuan et al., "Microbiology and potential applications of aerobic methane oxidation coupled to denitrification (AME-D) process: a review," Water Research, vol. 90, pp. 203-215, 2016.

[60] M. Kumar, G. Rattan, and R. Prasad, "Catalytic abatement of methane emission from CNG vehicles: an overview," Canadian Chemical Transactions, vol. 3, no. 4, pp. 381-409, 2015.

[61] A. A. Olajire, " $\mathrm{CO}_{2}$ capture and separation technologies for endof-pipe applications-a review," Energy, vol. 35, no. 6, pp. 26102628, 2010.

[62] M. K. Mondal, H. K. Balsora, and P. Varshney, "Progress and trends in $\mathrm{CO}_{2}$ capture/separation technologies: a review," Energy, vol. 46, no. 1, pp. 431-441, 2012.

[63] L. Meier, R. Pérez, L. Azócar, M. Rivas, and D. Jeison, "Photosynthetic $\mathrm{CO}_{2}$ uptake by microalgae: an attractive tool for biogas upgrading," Biomass and Bioenergy, vol. 73, pp. 102-109, 2015.

[64] R. Wang, B. Peng, and K. Huang, "The research progress of $\mathrm{CO}_{2}$ sequestration by algal bio-fertilizer in China," Journal of $\mathrm{CO}_{2}$ Utilization, vol. 11, pp. 67-70, 2015.

[65] M. Dębowski, M. Zieliński, A. Grala, and M. Dudek, "Algae biomass as an alternative substrate in biogas production technologies-review," Renewable and Sustainable Energy Reviews, vol. 27, pp. 596-604, 2013.

[66] H. Gao, Y. D. Scherson, and G. F. Wells, "Towards energy neutral wastewater treatment: methodology and state of the art," Environmental Sciences: Processes \& Impacts, vol. 16, no. 6, pp. 1223-1246, 2014.

[67] D. Kim, J. D. Bowen, and E. C. Ozelkan, "Optimization of wastewater treatment plant operation for greenhouse gas mitigation," Journal of Environmental Management, vol. 163, pp. 39-48, 2015. 
[68] N. Morales, Á. Val del Río, J. R. Vázquez-Padín, R. Méndez, A. Mosquera-Corral, and J. L. Campos, "Integration of the Anammox process to the rejection water and main stream lines of WWTPs," Chemosphere, vol. 140, pp. 99-105, 2015.

[69] H. Siegrist, D. Salzgeber, J. Eugster, and A. Joss, "Anammox brings WWTP closer to energy autarky due to increased biogas production and reduced aeration energy for N-removal," Water Science and Technology, vol. 57, no. 3, pp. 383-388, 2008.

[70] R. Khiewwijit, H. Temmink, H. Rijnaarts, and K. J. Keesman, "Energy and nutrient recovery for municipal wastewater treatment: how to design a feasible plant layout?" Environmental Modelling \& Software, vol. 68, pp. 156-165, 2015.

[71] Y. D. Scherson, S.-G. Woo, and C. S. Criddle, "Production of nitrous oxide from anaerobic digester centrate and its use as a co-oxidant of biogas to enhance energy recovery," Environmental Science and Technology, vol. 48, no. 10, pp. 56125619, 2014.

[72] B. Kartal, M. M. M. Kuypers, G. Lavik et al., "Anammox bacteria disguised as denitrifiers: nitrate reduction to dinitrogen gas via nitrite and ammonium," Environmental Microbiology, vol. 9, no. 3, pp. 635-642, 2007.

[73] M. Strous, J. J. Heijnen, J. G. Kuenen, and M. S. M. Jetten, “The sequencing batch reactor as a powerful tool for the study of slowly growing anaerobic ammonium-oxidizing microorganisms," Applied Microbiology and Biotechnology, vol. 50, no. 5, pp. 589-596, 1998.

[74] S. Wyffels, P. Boeckx, K. Pynaert, W. Verstraete, and O. Van Cleemput, "Sustained nitrite accumulation in a membraneassisted bioreactor (MBR) for the treatment of ammonium-rich wastewater," Journal of Chemical Technology \& Biotechnology, vol. 78, no. 4, pp. 412-419, 2003.

[75] M. J. Kampschreur, R. Poldermans, R. Kleerebezem et al., "Emission of nitrous oxide and nitric oxide from a full-scale single-stage nitritation-anammox reactor," Water Science and Technology, vol. 60, no. 12, pp. 3211-3217, 2009.

[76] J. Yang, J. Trela, E. Plaza, and K. Tjus, " $\mathrm{N}_{2} \mathrm{O}$ emissions from a one stage partial nitrification/anammox process in moving bed biofilm reactors," Water Science and Technology, vol. 68, no. 1, pp. 144-152, 2013.

[77] S. Lackner, E. M. Gilbert, S. E. Vlaeminck, A. Joss, H. Horn, and M. C. M. van Loosdrecht, "Full-scale partial nitritation/anammox experiences-an application survey," Water Research, vol. 55, pp. 292-303, 2014.

[78] B. Ma, S. Wang, S. Cao et al., "Biological nitrogen removal from sewage via anammox: recent advances," Bioresource Technology, vol. 200, pp. 981-990, 2016.

[79] T. Muangthong-on and C. Wantawin, "Evaluation of $\mathrm{N}_{2} \mathrm{O}$ production from anaerobic ammonium oxidation (Anammox) at different influent ammonia to nitrite ratios," Energy Procedia, vol. 9, pp. 7-14, 2011.

[80] J. Myung, Z. Wang, T. Yuan et al., "Production of nitrous oxide from nitrite in stable type II methanotrophic enrichments," Environmental Science and Technology, vol. 49, no. 18, pp. 10969-10975, 2015.

[81] J. B. K. Park and R. J. Craggs, "Nutrient removal in wastewater treatment high rate algal ponds with carbon dioxide addition," Water Science and Technology, vol. 63, no. 8, pp. 1758-1764, 2011.

[82] C. Alcántara, R. Muñoz, Z. Norvill, M. Plouviez, and B. Guieysse, "Nitrous oxide emissions from high rate algal ponds treating domestic wastewater," Bioresource Technology, vol. 177, pp. 110-117, 2015.
[83] A. I. Barros, A. L. Gonçalves, M. Simões, and J. C. M. Pires, "Harvesting techniques applied to microalgae: a review," Renewable and Sustainable Energy Reviews, vol. 41, pp. 1489-1500, 2015.

[84] B. D. Shoener, I. M. Bradley, R. D. Cusick, and J. S. Guest, "Energy positive domestic wastewater treatment: the roles of anaerobic and phototrophic technologies," Environmental Sciences: Processes \& Impacts, vol. 16, no. 6, pp. 1204-1222, 2014.

[85] N. C. Boelee, H. Temmink, M. Janssen, C. J. N. Buisman, and R. H. Wijffels, "Scenario analysis of nutrient removal from municipal wastewater by microalgal biofilms," Water, vol. 4, no. 2, pp. 460-473, 2012.

[86] Y. Su, A. Mennerich, and B. Urban, "Synergistic cooperation between wastewater-born algae and activated sludge for wastewater treatment: influence of algae and sludge inoculation ratios," Bioresource Technology, vol. 105, pp. 67-73, 2012.

[87] W. Abma, C. Schultz, J. M. Mulder et al., "The advance of anammox," Water21, vol. 36, pp. 36-37, 2007.

[88] S. Lackner, E. M. Gilbert, S. E. Vlaeminck, A. Joss, H. Horn, and M. C. M. van Loosdrecht, "Full-scale partial nitritation/anammox experiences: an application survey," Water Research, vol. 55, pp. 292-303, 2014.

[89] A. Malovanyy, J. Trela, and E. Plaza, "Mainstream wastewater treatment in integrated fixed film activated sludge (IFAS) reactor by partial nitritation/anammox process," Bioresource Technology, vol. 198, pp. 478-487, 2015.

[90] R. J. Craggs, S. Heubeck, T. J. Lundquist, and J. R. Benemann, "Algal biofuels from wastewater treatment high rate algal ponds," Water Science and Technology, vol. 63, no. 4, pp. 660665, 2011. 

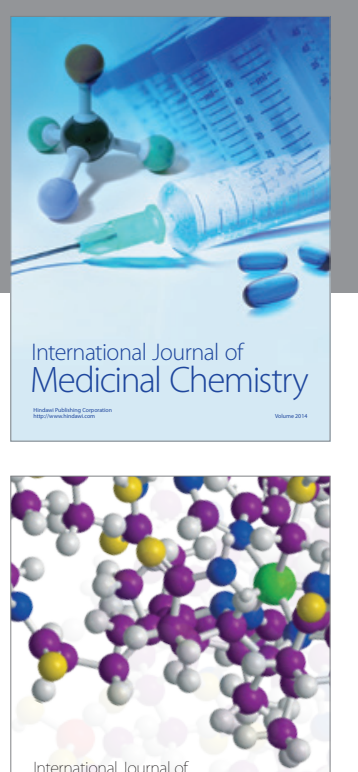

Carbohydrate Chemistry

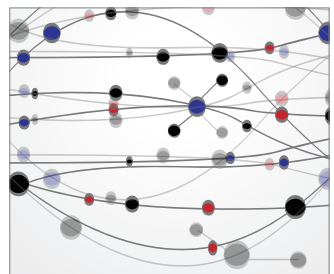

The Scientific World Journal
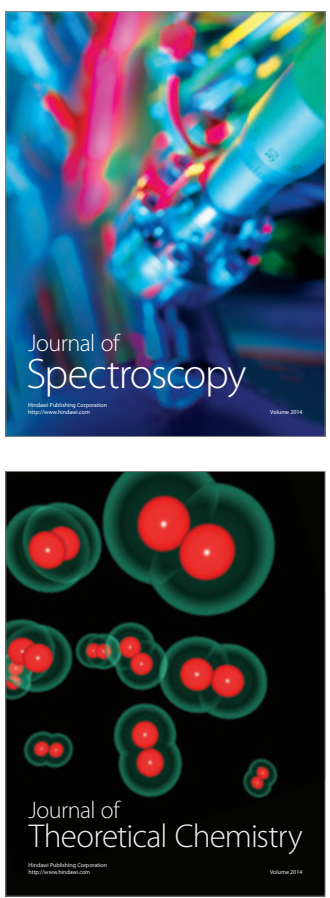
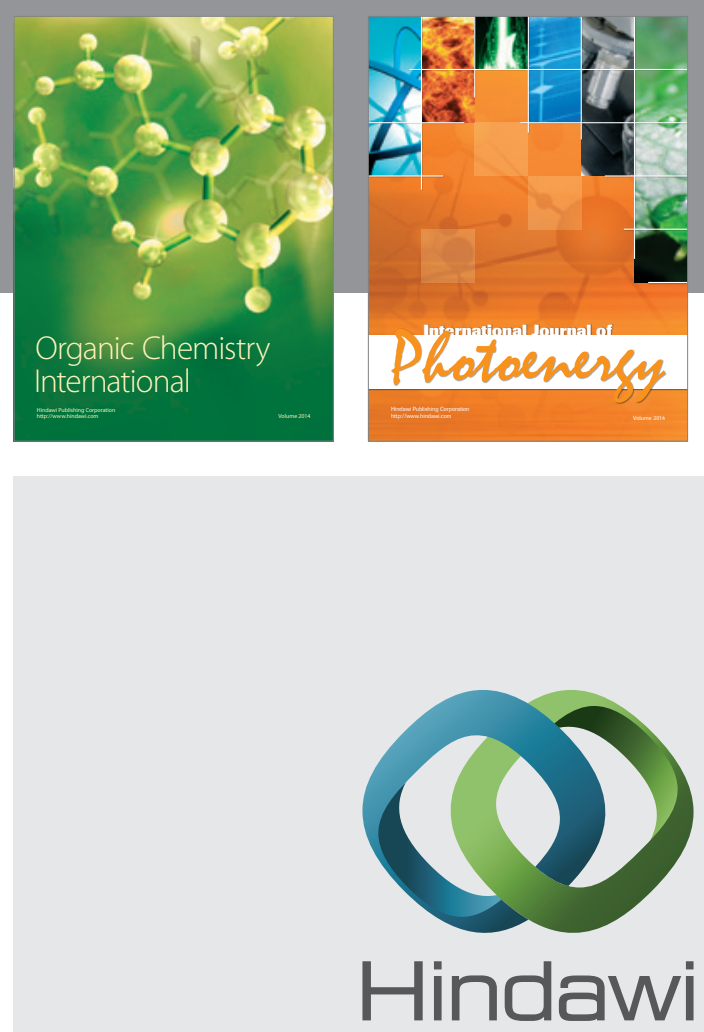

Submit your manuscripts at

http://www.hindawi.com

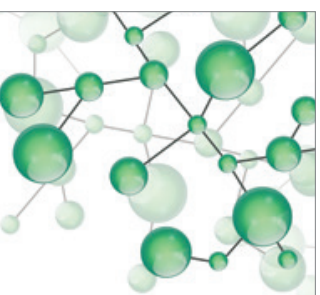

International Journal of

Inorganic Chemistry

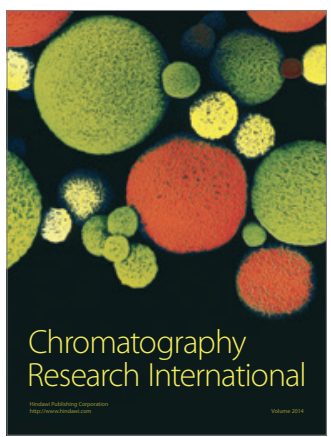

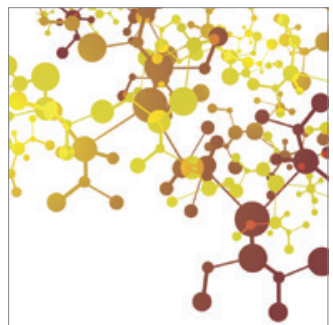

Applied Chemistry
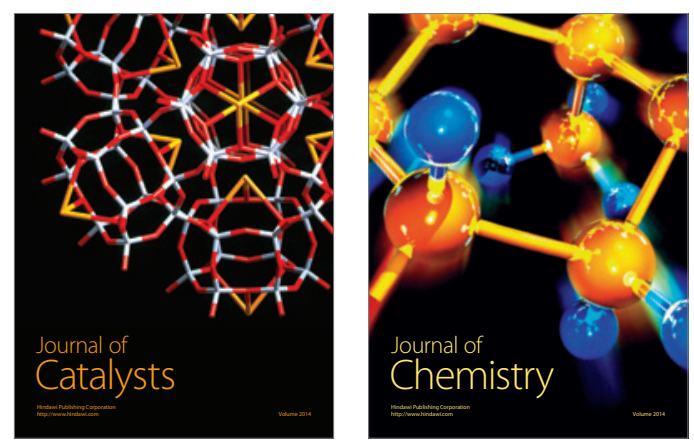
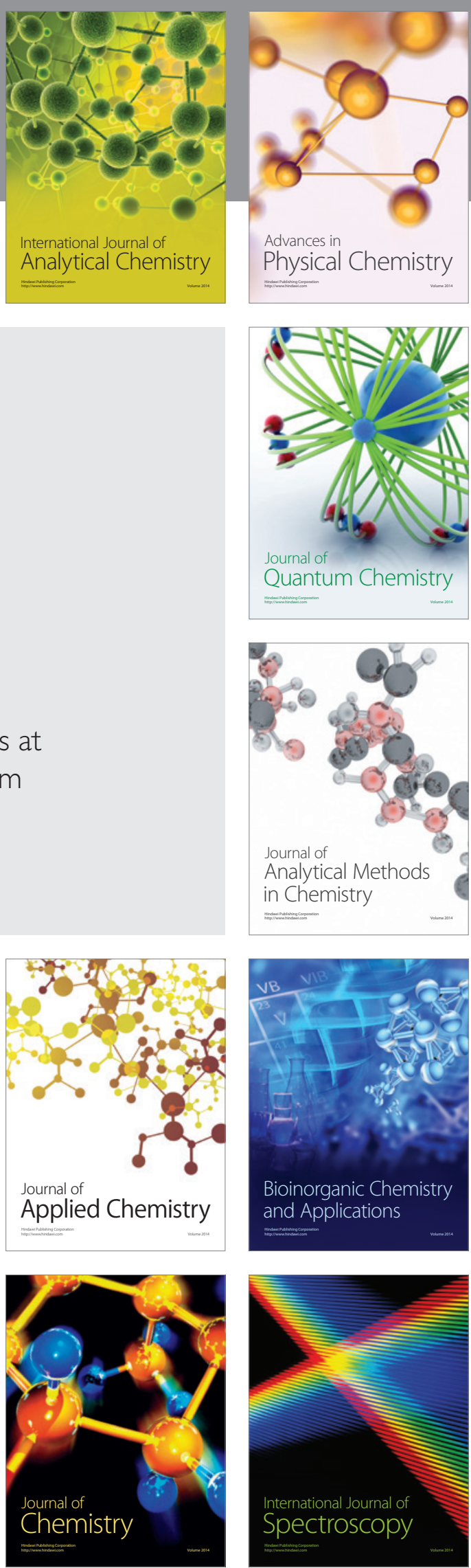